\title{
ANALYSIS OF GREEN ECONOMY DIMENSION IN THE CONTEXT OF CIRCULAR ECONOMY: THE CASE OF BALTIC SEA REGION
}

\section{Jelena Stankevičienè ${ }^{1}$, Marta Nikanorova ${ }^{2}$, Gentjan Çera ${ }^{3}$}

\footnotetext{
1 Vilnius Gediminas Technical University, Faculty of Business Management, Department of Financial Engineering, Lithuania, ORCID: 0000-0002-5600-5842, e-mail: jelena.stankeviciene@vgtu.lt;

2 Vilnius Gediminas Technical University, Faculty of Business Management, Department of Financial Engineering, Lithuania, ORCID: 0000-0002-1947-9766, e-mail: marta.nikanorova@vgtu.com;

3 Tomas Bata University, Faculty of Management and Economics, Department of Business Administration, Czech Republic, ORCID: 0000-0002-9324-181X, e-mail: cera@utb.cz.
}

\begin{abstract}
The circular economy is based on the synergy of economic, environmental and social dimensions on -micro, -meso and -macro levels. Integration of circular economy would help to shift from a linear economy, which promotes "take-make-waste" industrial model to a more effective economic system that is based on business models, which replace the "end-of-life" concept with reducing, alternatively reusing, recycling and recovering materials in production/distribution and consumption processes. This alternative model would encourage producers to develop innovative solutions to reduce production waste, be in the line of "green" production and resourceefficient usage. A circular economy would help to solve problems of resource shortage, negative environmental impact, production and consumption waste by developing closer relationships between suppliers, manufacturers, retailers and consumers. Regulation and policy determents may influence consumer behaviour by promoting investment into environmental and social drivers, subsidiaries for eco-innovation and eco-technology development, and supporting inefficient consumption taxes and production pollution taxes. The purpose of the article is to propose a way of analysing of green economy dimension in the context of circular economy, by providing empirical tests on economic data of Baltic Sea Region countries. The current paper includes the observation of green economy dimension in the context of circular economy in Baltic Sea Region including Green investment, Green fiscal policy, and Technological development. A multi-criteria decision analysis methods TOPSIS and MULTIMOORA were used to compare the set of indicators by identifying weights for each criterion. TOPSIS and MULTIMOORA are quite useful methods to rank and make selection of several indicators.
\end{abstract}

Keywords: Circular economy, green economy, TOPSIS, MULTIMOORA, Baltic states.

JEL Classification: G34, M12.

APA Style Citation: Stankevičienè, J., Nikanorova, M., \& Çera, G. (2020). Analysis of Green Economy Dimension in the Context of Circular Economy: The Case of Baltic Sea Region. E\&M Economics and Management, 23(1), 4-18. https://doi.org/10.15240/tul/001/2020-1-001

\section{Introduction}

Sustainability and sustainable economic development nowadays have become essential goals the world is challenged to achieve and a constant concern for policymakers (Garud \& Gehman, 2012; Markard, Raven, \& Truffer,
2012; Millar, McLaughlin, \& Börger, 2019). Nowadays, the world is facing with the problem related to the inefficiently used resources and increased generated waste (D'Amato et al., 2017). The current economic model uses "takemake-waste" industrial model known as linear 
economy (make, use, dispose) (Kalmykova, Sadagopan, \& Rosado, 2018). This paradigm does not take into account the fact that there is a limited amount of resources. Therefore, the world could face serious problems such as resource shortage due to the increasing economic volumes and amount of resources used to produce and offer goods and services. The main substantial issue of circular economy - efficient resource usage and minimal generated waste (Murray, Skene, \& Haynes, 2017). According to scholars, circular economy consists of economic, environmental and social dimensions (Millar et al., 2019).

Another way proposed in the literature that can be adopted to transform the linear economy toward a more sustainable one is green economy (D'Amato et al., 2017). The aim of the green economy is to link together poverty alleviation and environmental conservation (Barbier, 2012). According to the green economy principles, ecosystems provide vital benefits for the society and economy. These benefits are often invisible. In this regard, green economy dimension is seen as a compelling way toward a more sustainable economy (Puppim de Oliveira et al., 2013) even within the European Union (EU) (Lund, 2012).

Specific interconnection between circular and green economy are foreseen. A study on a comparative analysis of sustainability paths conducted by D'Amato et al. (2017), argues that circular and green economy overlaps in terms of eco-efficiency. However, there are divergences between them. While green economy covers all-natural processes, circular economy focuses on urbanisation. The current literature on this field of study is mainly populated by papers aimed at definitions of certain concepts dealing with sustainability and their conceptualisations (Gregorio, Pié, \& Terceño, 2018; Kirchherr, Reike, \& Hekkert, 2017). Consequently, there is a need to advance in exploring and analysing green economy dimension in the context of circular economy.

The purpose of the current paper is to analyse the green economy dimension in the context of the circular economy. It contributes in this regard by providing empirical tests on economic data of Baltic Sea Region countries. This study provides useful insights on evaluating the green economy in the context of circular economy and could be used for scientific, statistical and strategic purposes as by scientists, as well by business, industry and government.

The remainder of this paper is organised as follow. The concept of the circular and green economy are discussed under theoretical background section. We then outline our methodological aspects used to achieve our aim. Particular sub-section is dedicated to two multi-criteria decision analysis methods such as Technique for Order of Preference by Similarity to Ideal Solution (TOPSIS) (Hwang \& Yoon, 1981) and Multi-Objective Optimization by Ratio Analysis Full Multiplicative Form (MULTIMOORA) (Brauers \& Zavadskas, 2010), were used to compare the set of indicators by identifying weights for each criterion.

\section{Theoretical Background 1.2 The Concept of Circular Economy}

The fast-technological progress, rapid industrialisation and urbanisation lead to the increasing production volumes and consumption. During recent years, this progress made a negative impact on the environment. Today, the environment and reduction of waste are most common topics to discuss by society. The regions and countries are establishing more and more regulations and laws to reduce the negative impact on the environment by involving recycling into economics. For instance, Germany, Japan, China, the United Kingdom, the Netherlands, Sweden and EU have established several directives leading the economy towards the circular economy concept by introducing the framework of closed-cycle waste management ensuring waste disposal, which moves towards recycling-based society (Cheng, 2016). Some EU countries have established "green" politics in their political decision making which encourages the movement towards circular economy (Howes et al., 2017). EU has put lot of efforts to move towards Circular Economy by the issued directive "European Resource Efficiency Platform (EREP) - Manifesto and Policy Recommendations" (European Commission, 2014). This Platform is calling on the society, including business, manufactures and labour, to support the reduction of waste and increase resource efficiency by providing an action plan for transitioning to resourceefficient Europe which includes the encourage to produce and use renewable energy, to manage the waste. 
There are different definitions of circular economics proposed by scientists. According to Kirchherr et al. (2017), "a circular economy describes an economic system that is based on business models which replace the 'end-of-life' concept with reducing, alternatively reusing, recycling and recovering materials in production/ distribution and consumption processes, thus operating at the micro-level (products, companies, consumers), meso-level (ecoindustrial parks) and macro-level (city, region, nation and beyond), with the aim to accomplish sustainable development, which implies creating environmental quality, economic prosperity and social equity, to the benefit of current and future generations". Geissdoerfer, Savaget, Bocken and Hultink (2017) introduced the definition of circular economy as a regenerative system in which resource input and waste, emission, and energy leakage are minimised by slowing, closing, and narrowing material and energy loops. It can be achieved through long-lasting design, maintenance, repair, reuse, remanufacturing, refurbishing, and recycling. Second, we define sustainability as the balanced integration of economic performance, social inclusiveness, and environmental resilience, to the benefit of current and future generations (D'Amato et al., 2017). In addition to this, Stahel (2016) defined that a "circular economy would turn goods that are at the end of their service life into resources for others, closing loops in industrial ecosystems and minimising waste. It would change economic logic because it replaces production with sufficiency: reuse what you can, recycle what cannot be reused, repair what is broken, remanufacture what cannot be repaired".

By all these definitions circular economy is introduced as a closed loop of the economy, where resources are extracted, transformed to the good, distributed among consumers, used and recycled in order to be returned into the resource which can be ready for transformation into the good (Fig. 1). All these processes are integrated on -micro, -meso and -macro levels.

With the development of economy, the industries are increasing amounts of production consuming more energy (Gasparatos, Doll, Esteban, Ahmed, \& Olang, 2017). Circular economy encourages the switch from nonrenewable energy sources to renewable "green" energy sources reducing pollution and energy waste. It leads to implementation of new "green" standards in production and developing new technologies. The main aspects of implementing and developing circular economy (Heshmati, 2016) are - land degradation, deforestation, water depletion, air pollution, loss of biodiversity, generation of waste, shortage of resources and energy to meet the growing demand.

According to Taranic, Behrens and Topi (2016), the circular economy would help to solve problems of resource shortage, negative environmental impact, production and consumption waste. A circular economy would develop closer relationships between suppliers, manufacturers, retailers and consumers. It would lead to efficient use of resources, "zero" waste approach and extended product life cycle (Vasiljevic-Shikaleska, Gjozinska, \& Stojanovikj, 2017). In addition to this, Murray et al. (2017) defines the use of word "restorative" necessary talking about circular economy approach, as this approach is not a preventive tool to reduce pollution of the environment, but also, circular economy is able to repair previously damaged by designing better systems within the industry.

\subsection{Analysis of Green Economy Indicators}

Implementation of the circular economy requires synergy of economic, environmental and social dimensions on all three levels (-micro, -meso, -macro) (Loiseau et al., 2016). To achieve the implementation of circular economy there is a need for legislation oriented towards ecoinnovations, production and consumption ecoinnovative standards. In the case legislation, production and consumption are interrelated and interacted, and the circular economy could be applied (Scheel, 2016). Regulation and policy may influence consumer behaviour of environmental practices, while it will encourage producers to develop innovative solutions to reduce production waste, be in the line of "green" production (Kalmykova, Rosado, \& Patrício, 2016), while policy determents should support inefficient consumption taxes, production pollution taxes, subsidiaries for eco-innovation and eco-technology development, low-interest rate and promotion of the investment into environmental and social drivers. It can be stated that the Green investment, Green fiscal policy and technological development towards eco-innovation should be promoted and developed (Fig. 2). 


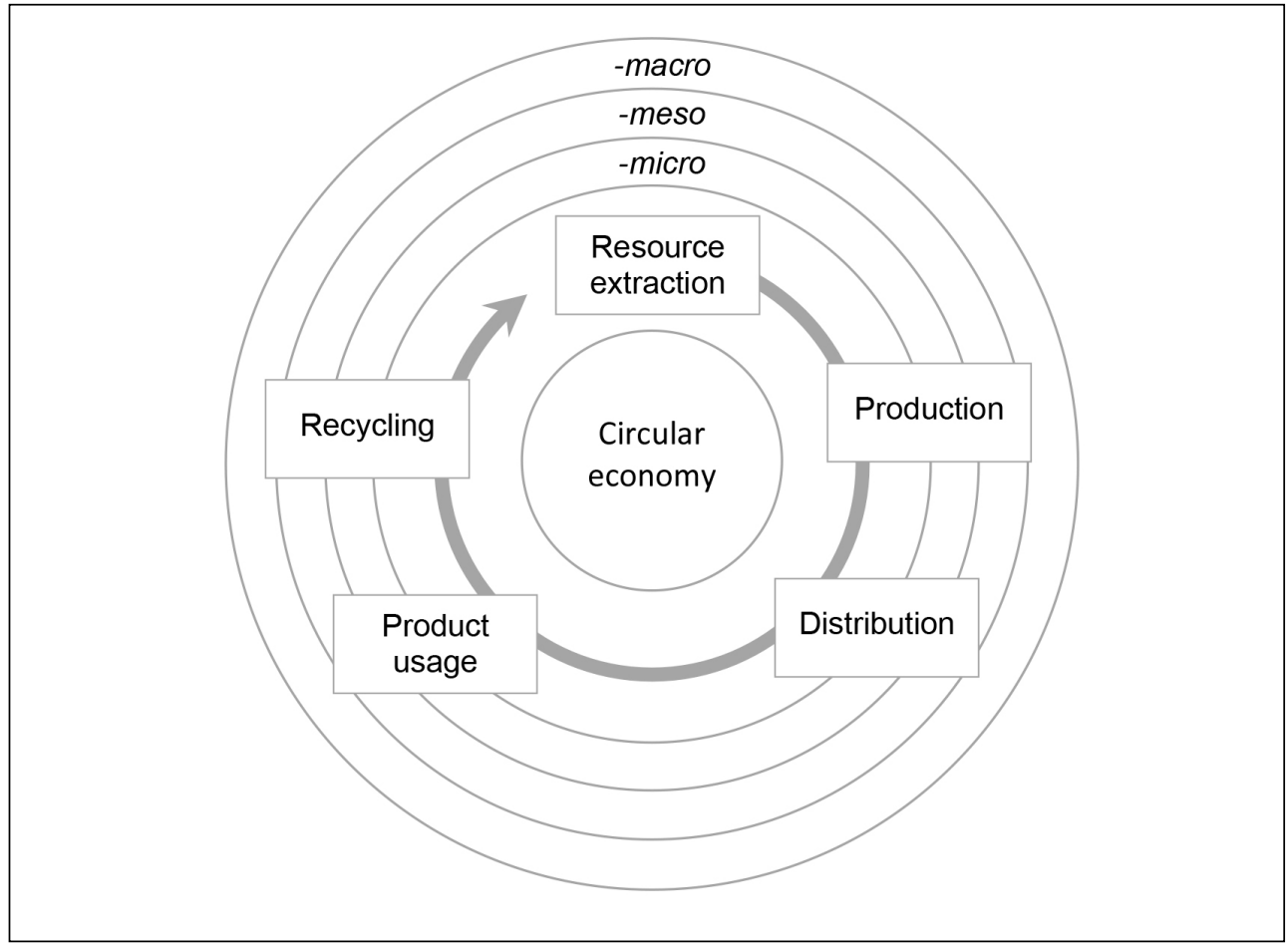

Source: made by authors based on Kirchherr et al. (2017)

Official Development Assistance (ODA) consists of grants or loans that are undertaken by the official sector with the purpose of promoting economic development and welfare (United Nations, 2016). According to llić et al. (2016), the promotion of Green investment considering well-being more than economic interest should be implemented by the policy owners (Ringel, Schlomann, Krail, \& Rohde, 2016). Besides, regulation and policy determents are promoting clean production and pollution taxes. The European Union contributes to global environmental, usage of "green" energy, resource efficiency and minimisation of pollution challenges by implementing Horizon 2020 programme. Horizon 2020 is the biggest EU research and innovation programme starting from 2014. Horizon 2020 includes energy efficiency problems, such as reducing energy consumption, alternative fuels and mobile energy sources, low cost and low carbon electricity supply, reduction of air pollution, development of new knowledge and technologies (European Commission, 2014). To sum up, the Green fiscal policy based on Horizon 2020 includes Energy-related tax and Environmental tax.

Environmentally related taxes are taxes whose tax base is a physical unit (or a proxy of it) of something that has a proven, specific negative impact on the environment and include (Green Growth Knowledge Platform, 2017): energy products for transport and stationary purposes; motor vehicles and transport; waste management; ozone-depleting substances, and other taxes.

A circular economy is based on three dimensions principle: economic, environmental and social. The green economy dimension is analysed through three dimensions: Green investment dimension is being analysed as Economic aspect, Green fiscal policy as Environmental aspect and Technological 


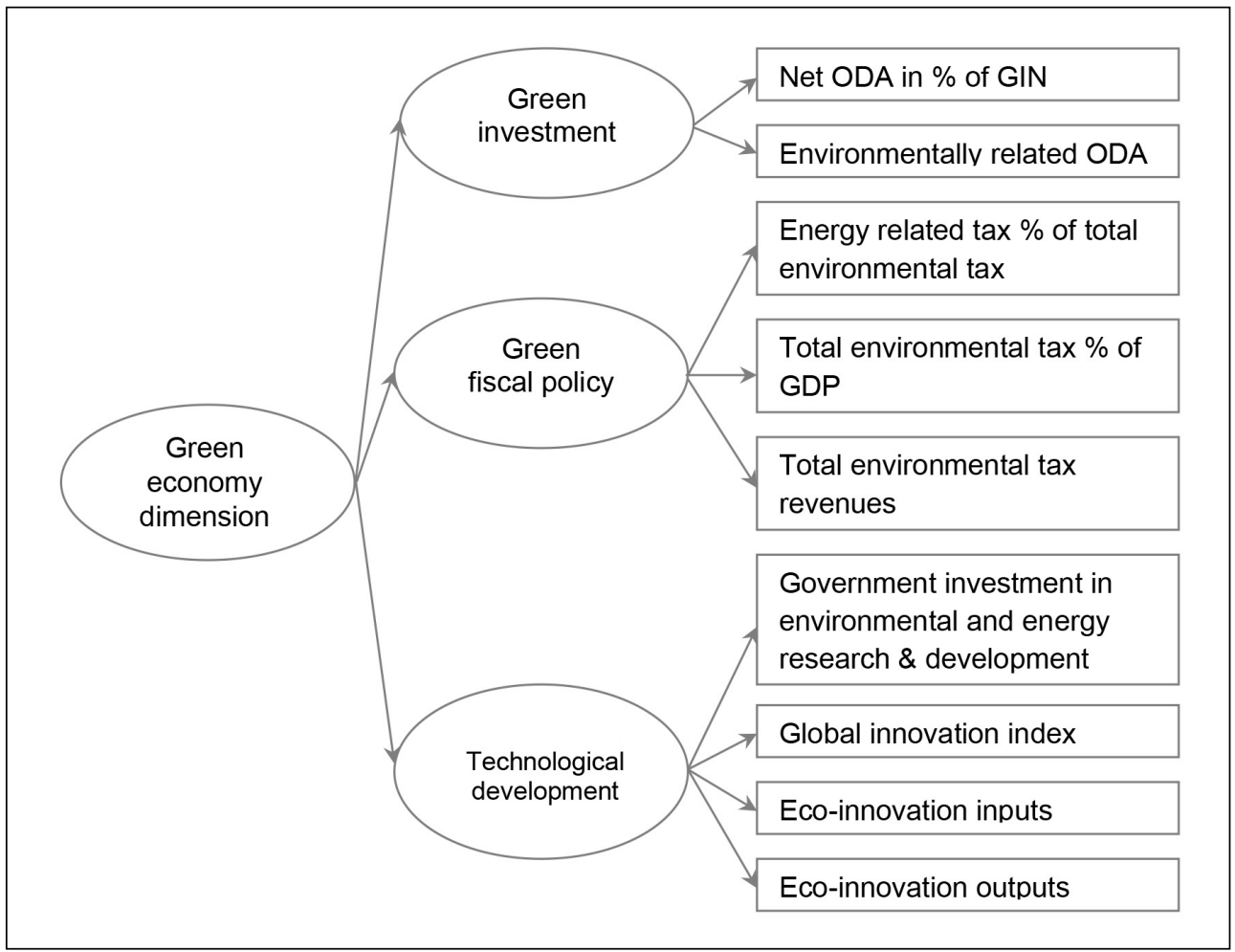

Source: compiled by authors

development as Social aspect (D'Amato et al., 2017). The Development of Eco-Innovations and Technologies are one of the key drivers for implementation of circular economy. The more policy determents support Innovation; the more progress could lead to a zero-waste approach of producers and consumers. The core of the Global Innovation Index Report consists of a ranking of world economies' innovation capabilities and results. Recognising the key role of innovation as a driver of economic growth and prosperity, and the need for a broad horizontal vision of innovation applicable to developed and emerging economies, the Global Innovation Index includes indicators that go beyond the traditional measures of innovation such as the level of research and development. Eco-Innovation output/ input is calculated based on three indicators: government investments in environmental and energy research and development, green early-stage investments and total research and development personnel.

\section{Aim, Methodology and Data}

3.1 Aim

This paper seeks to analyse the green economy dimension in the context of a circular economy for countries in the Baltic Sea Region, as one of the biggest "macro-region" in Europe.

To achieve this aim, two multi-criteria decision analysis methods such as TOPSIS (Hwang \& Yoon, 1981) and MULTIMOORA (Brauers \& Zavadskas, 2010), are performed. In the following sub-section are described these methods. We used secondary data to measure all the sub-dimensions of green economy presented in Fig. 2. 


\section{Tab. 1: TOPSIS and MULTIMOORA MCDA methods}

\section{TOPSIS}

MULTIMOORA

Decision matrix for TOPSIS and MULTIMOORA methods

$$
\mathrm{A}=\left(a_{i j}\right)=\left[\begin{array}{ccc}
a_{11} & \cdots & a_{1 n} \\
\vdots & \ddots & \vdots \\
a_{m 1} & \cdots & a_{m n}
\end{array}\right]
$$

where: $a_{m n}$ represents alternative value

The normalisation of the criteria

$$
\widetilde{r_{l j}}=\frac{r_{i j}}{\sqrt{\sum_{j=1}^{n} r_{i j}^{2}}}
$$

(Byun \& Lee, 2005)

where: $i=1, \ldots, m ; j=1, \ldots, n$;

Each criterion should be multiplied by the establish weight

$$
x_{i j}=\frac{x_{i j}}{\sqrt{\sum_{j=1}^{m} x_{i j}^{2}}}
$$

(Brauers \& Zavadskas, 2012) where: $j=1,2, \ldots, m ; i=1,2, \ldots, n$;

Values are optimised according to the need of minimisation/maximisation

$v_{i j}=w_{i j}^{*} r_{i j}$

$$
y_{j}=\sum_{i=1}^{i=g} x_{i j}-\sum_{i=g+1}^{i=n} x_{i j}
$$

where: $i=1, \ldots, m ; j=1, \ldots, n$;

with $i=1,2, \ldots ; g$ as the objectives to be maximized; $i=g+1, g+2, \ldots ; n$ as the objectives to be minimized;

The best hypothetical solution $V^{*}$ and the worst hypothetical solution $V^{-}$

$V^{*}=\left\{V_{1}^{*}, V_{2}^{*}, \ldots, V_{m}^{*}\right\}=\left\{\left(\max _{j} \omega_{i} \tilde{r}_{i j} / i \in I_{1}\right),\left(\min _{j} \omega_{i} \tilde{r}_{i j} / i \in I_{2}\right)\right\}$,

$V^{-}=\left\{V_{1}^{-}, V_{2}^{-}, \ldots, V_{m}^{-}\right\}=\left\{\left(\min _{i} \omega_{i} \tilde{r}_{i j} / i \in I_{1}\right),\left(\max \omega_{i} \tilde{r}_{i j} / i \in I_{2}\right)\right\}$,

(Podviezko, 2012)

where: $I_{1}$ is the set of indices of the maximising criteria;

$I_{2}$ is the set of indices of the minimising criteria.

The Euclidean distance to the best and the worst hypothetical solutions

$$
\begin{aligned}
& D_{j}^{*}=\sqrt{\sum_{i=1}^{m}\left(\omega_{i} \tilde{r}_{i j}-V_{i}^{*}\right)^{2}} \\
& D_{j}^{-}=\sqrt{\sum_{i=1}^{m}\left(\omega_{i} \tilde{r}_{i j}-V_{i}^{-}\right)^{2}}
\end{aligned}
$$

Maximal Objective Reference Point

$$
\min _{(j)}\left\{\max _{(i)}\left|r_{i}-x_{i j}\right|\right\}
$$

(Brauers \& Zavadskas, 2010)

with $\left|r_{i}-x_{i j}\right|$ the absolute value if $x_{i j}$ is larger than $r_{i}$ by minimisation

Reference Point Approach the place of the significance coefficient

$$
\left|s_{i} r_{i}-s_{i} x_{i j}\right|
$$

(Brauers \& Zavadskas, 2010)

\section{Cumulative criterion}

Full-Multiplicative Form

$$
C_{j}^{*}=\frac{D_{j}^{-}}{D_{j}^{*}+D_{j}^{-}} \quad(j=1,2, \ldots, n)
$$

(Pavić \& Novoselac, 2013)

$$
U_{j}=\prod_{i=1}^{n} x_{i j}
$$

(Brauers \& Zavadskas, 2010) 


\subsection{Green Economy Assessment Based on TOPSIS and MULTIMOORA Methods}

Multi-criteria Decision Aid is a process of decision-making where the criteria could be found out. MCDA methods have a wellstructured framework which helps to determine the criteria by setting weights and ranks. By the setting of weights and ranks the importance of criteria is being assured. MCDA can help to be well oriented among different alternatives, which could be grouped, ranked or classified.

TOPSIS and MULTIMOORA belong to MCDA group, and both methods allow analysing the data without considering the units of measurement (Tab. 1). The basic idea of the TOPSIS method is that the best alternative would be the closest to the best solution and far away from the worst solution. In other words, TOPSIS method measures the distance to the ideal solution, or the shortest geometric distance (Sarkar, 2013). Also, the TOPSIS method includes weights for criterion, requires a set of alternatives and normalisation.

MULTIMOORA method is widely used by researches in different study fields, is flexible, can be quickly adapted to the analysis of several factors affecting the objective, can solve multi-criteria questions, can rank the objectives according the selected indicators (Brauers \& Zavadskas, 2010). The method does not require complicated mathematical calculations. It can be easily implemented in the case of existing different indicators; which value differs in the meaning of maximisation and minimisation.

\subsection{Research Object Selection and Data Collection}

The Baltic Sea Region was targeted as 'macro-region' by the European Commission in 2009. The European Union Strategy for the Baltic Sea Region (EUSBSR) is the first EU strategy for targeting 'macro-region'. Eight countries (Sweden, Denmark, Estonia, Finland, Germany, Latvia, Lithuania and Poland) participate in the same strategic action plan of the common region to save the sea and connect the region. Moreover, the EUSBSR helps to promote sustainable development of the region. The statistical data for the period of 2013-2015 of Baltic Sea Region was collected using the databases: European Statistical Database (EUROSTAT, n.d.), United Nation database (UNSD, n.d.) and Organization for Economic Co-Operation and Development (OECD, n.d.).

\begin{tabular}{|c|c|c|c|c|c|c|}
\hline \multirow{2}{*}{ \# } & \multirow{2}{*}{ Economic and social indicators } & Criteria & Sweden & Denmark & Estonia & Finland \\
\hline & & Max/Min & 2013 & 2013 & 2013 & 2013 \\
\hline 1. & $\begin{array}{l}\text { Net official development assistance } \\
(\% \text { of GNI) }\end{array}$ & Max & 1.01 & 0.85 & 0.13 & 0.54 \\
\hline 2. & $\begin{array}{l}\text { Environmentally-related official } \\
\text { development assistance }\end{array}$ & Max & 5.15 & 14.26 & 5.06 & 2.18 \\
\hline 3. & $\begin{array}{l}\text { Energy related tax } \% \text { of total } \\
\text { environmental tax }\end{array}$ & Min & 4.42 & 5.19 & 7.03 & 4.48 \\
\hline 4. & Total environmental tax $\%$ of GDP & Min & 2.36 & 4.11 & 2.57 & 2.93 \\
\hline 5. & Total environmental tax revenues & Min & 5.51 & 8.90 & 8.09 & 6.71 \\
\hline 6. & $\begin{array}{l}\text { Government investment in } \\
\text { Environmental and Energy Research } \\
\text { and Development (GBAORD) }\end{array}$ & Max & 23.00 & 30.50 & 8.10 & 36.30 \\
\hline 7. & Global Innovation Index (GII) & Max & 61.40 & 58.30 & 50.60 & 59.50 \\
\hline 8. & Eco-innovation input & Max & 184.00 & 145.00 & 98.00 & 220.00 \\
\hline 9. & Eco-innovation outputs & Max & 176.00 & 184.00 & 67.00 & 164.00 \\
\hline
\end{tabular}




\begin{tabular}{|c|c|c|c|c|c|c|}
\hline Tab. 3: & \multicolumn{6}{|c|}{$\begin{array}{l}\text { Economic and social indicators of Germany, Latvia, Lithuania and Poland } \\
\text { in } 2013\end{array}$} \\
\hline \multirow{2}{*}{ \# } & \multirow{2}{*}{ Economic and social indicators } & Criteria & Germany & Latvia & Lithuania & Poland \\
\hline & & Max/Min & 2013 & 2013 & 2013 & 2013 \\
\hline 1. & $\begin{array}{l}\text { Net official development assistance } \\
\text { (\% of } \mathrm{GNI})\end{array}$ & Max & 0.38 & 0.08 & 0.11 & 0.10 \\
\hline 2. & $\begin{array}{l}\text { Environmentally-related official } \\
\text { development assistance }\end{array}$ & Max & 8.17 & 2.19 & 0.01 & 7.34 \\
\hline 3. & $\begin{array}{l}\text { Energy related tax } \% \text { of total } \\
\text { environmental tax }\end{array}$ & Min & 4.46 & 6.67 & 5.68 & 6.66 \\
\hline 4. & Total environmental tax $\%$ of GDP & Min & 2.46 & 2.45 & 1.64 & 2.41 \\
\hline 5. & Total environmental tax revenues & Min & 5.34 & 8.55 & 6.04 & 7.53 \\
\hline 6. & $\begin{array}{l}\text { Government investment in } \\
\text { Environmental and Energy Research } \\
\text { and Development (GBAORD) }\end{array}$ & Max & 23.60 & 2.80 & 2.10 & 3.00 \\
\hline 7. & Global Innovation Index (GII) & Max & 55.80 & 45.20 & 41.40 & 40.10 \\
\hline 8. & Eco-innovation inputs & $\operatorname{Max}$ & 132.00 & 30.00 & 39.00 & 18.00 \\
\hline 9. & Eco-innovation outputs & $\operatorname{Max}$ & 164.00 & 101.00 & 110.00 & 54.00 \\
\hline
\end{tabular}

The Green economy dimension of the Baltic Sea Region was collected based on the economic, social and environmental aspects. The economic aspect was expressed by Green investment dimension, analysing the total Green investment as a percentage of $\mathrm{GNI}$ and Investment in the Environment. Green investment dimension was represented as Net Official Development Assistance (\% of $\mathrm{GNI}$ ) and Environmentally-related Official Development Assistance. The environmental aspect was represented by Green fiscal policy including Environmental taxes and their percentage of GDP. Green fiscal policy included Energy-related Tax (as \% of total Environmental Tax), Total Environmental Tax (as \% of GDP) and Total Environmental Tax revenues. The social aspect was introduced by Technological development including the development of ecoinnovations and technologies as a progressive tool towards Circular Economy.

Economic and social indicators of the Baltic Sea Region in 2013, are shown in Tab. 2 and Tab. 3, which were used in assessment of Green Economy Dimension by TOPSIS and MULTIMOORA methods.

Economic and social indicators of the Baltic Sea Region in 2014 and 2015 are illustrated in Tab. 4 and Tab. 5 accordingly, which were used in assessment of Green Economy
Dimension by TOPSIS and MULTIMOORA methods. The numbering and maximisation/ minimisation of indicators of Baltic Sea Region in 2013 presented in Tab. 2 and Tab. 3 remain the same for all further calculation based on MULTIMOORA and TOPSIS methods.

According to MULTIMOORA method, the selected criteria should be normalised and optimised according to the need of minimisation/ maximisation.

In Tab. 6 are represented optimised values for Sweden, Denmark, Estonia and Finland in the period of 2013-2015. In Tab. 7 are represented optimised values for Germany, Latvia, Lithuania and Poland in the period of 2013-2015.

\section{Results and Discussion}

According to the TOPSIS method, the selected criteria should be normalised and the best hypothetical solution $V^{*}$ and the worst hypothetical solution $V^{-}$should be calculated. Once the best and the worst hypothetical solutions are identified, the Euclidean distance to the best and the worst hypothetical solutions can be found out. Euclidean distance to the best and the worst hypothetical solution for Sweden, Denmark, Estonia, Finland, Germany, Latvia, Lithuania and Poland in the period 


\section{Tab. 4: Economic and social indicators of the Baltic Sea Region in 2014}

\begin{tabular}{c|c|c|c|c|c|c|c|c}
$\#$ & Sweden & Denmark & Estonia & Finland & Germany & Latvia & Lithuania & Poland \\
\cline { 2 - 9 } & $\mathbf{2 0 1 4}$ & $\mathbf{2 0 1 4}$ & $\mathbf{2 0 1 4}$ & $\mathbf{2 0 1 4}$ & $\mathbf{2 0 1 4}$ & $\mathbf{2 0 1 4}$ & $\mathbf{2 0 1 4}$ & $\mathbf{2 0 1 4}$ \\
\hline 1. & 1.09 & 0.86 & 0.14 & 0.59 & 0.42 & 0.08 & 0.10 & 0.09 \\
\hline 2. & 7.23 & 6.51 & 8.77 & 2.18 & 5.89 & 2.17 & 0.10 & 0.36 \\
\hline 3. & 4.11 & 4.71 & 7.20 & 4.44 & 4.35 & 7.24 & 5.75 & 6.93 \\
\hline 4. & 2.20 & 4.00 & 2.70 & 2.90 & 2.04 & 2.67 & 1.69 & 2.57 \\
\hline 5. & 5.18 & 8.12 & 8.28 & 6.62 & 5.20 & 9.21 & 6.13 & 8.02 \\
\hline 6. & 23.00 & 27.20 & 8.50 & 36.90 & 24.10 & 2.70 & 2.00 & 3.60 \\
\hline 7. & 62.30 & 57.50 & 51.50 & 60.70 & 56.00 & 44.80 & 41.00 & 40.60 \\
\hline 8. & 133.00 & 464.00 & 74.00 & 182.00 & 137.00 & 38.00 & 43.00 & 41.00 \\
\hline 9. & 154.00 & 155.00 & 36.00 & 167.00 & 168.00 & 85.00 & 47.00 & 52.00 \\
\hline
\end{tabular}

of 2013-2015 were calculated. The result of Green Economy Dimension assessment in the context of Circular Economy in Baltic Sea Region in 2013, using TOPSIS and MULTIMOORA MCDA methods, is illustrated in Figure 3. According to Fig. 3, the closest rank to the centre shows the highest evaluation of Green Economy Dimension in the context of Circular Economy.

According to MULTIMOORA results, the highest rank received Sweden, Denmark and Germany, while the lowest rank received Poland Latvia and Lithuania. By the result of TOPSIS method, the best result of Green Economy Dimension in 2013 had Sweden, Denmark and
Finland, while the weakest were Poland Latvia and Lithuania.

In Fig. 4 are represented results of Green Economy Dimension evaluation in the context of Circular economy of Baltic Sea Region in 2014.

According to MULTIMOORA results the highest rank received Denmark, Sweden, and Finland, while the lowest rank received Lithuania, Latvia and Poland. To compare to 2013 results, Finland and Lithuania improved their results, while Sweden and Germany rank was decreased. According to the TOPSIS method, the highest rank received Denmark, Sweden, and Finland, while the lowest rank received

Tab. 5: Economic and social indicators of the Baltic Sea Region in 2015

\begin{tabular}{c|c|c|c|c|c|c|c|c}
$\#$ & Sweden & Denmark & Estonia & Finland & Germany & Latvia & Lithuania & Poland \\
\cline { 2 - 9 } & $\mathbf{2 0 1 5}$ & $\mathbf{2 0 1 5}$ & $\mathbf{2 0 1 5}$ & $\mathbf{2 0 1 5}$ & $\mathbf{2 0 1 5}$ & $\mathbf{2 0 1 5}$ & $\mathbf{2 0 1 5}$ & $\mathbf{2 0 1 5}$ \\
\hline 1. & 1.40 & 0.85 & 0.15 & 0.55 & 0.52 & 0.09 & 0.13 & 0.10 \\
\hline 2. & 9.69 & 14.51 & 2.72 & 2.77 & 8.35 & 2.19 & 0.11 & 0.43 \\
\hline 3. & 4.03 & 4.75 & 7.16 & 4.53 & 4.13 & 7.15 & 5.74 & 7.00 \\
\hline 4. & 2.22 & 3.99 & 2.75 & 2.92 & 1.92 & 2.70 & 1.81 & 2.65 \\
\hline 5. & 5.14 & 8.56 & 8.13 & 6.65 & 4.97 & 9.28 & 6.24 & 8.17 \\
\hline 6. & 20.10 & 26.00 & 10.60 & 38.20 & 23.30 & 3.20 & 3.10 & 3.90 \\
\hline 7. & 62.40 & 57.70 & 52.80 & 60.00 & 57.10 & 45.50 & 42.30 & 40.20 \\
\hline 8. & 121.00 & 368.00 & 78.00 & 182.00 & 154.00 & 43.00 & 43.00 & 40.00 \\
\hline 9. & 160.00 & 157.00 & 53.00 & 190.00 & 140.00 & 95.00 & 59.00 & 58.00 \\
\hline
\end{tabular}




\begin{tabular}{|c|c|c|c|c|c|c|c|c|c|c|c|c|}
\hline \multicolumn{2}{|c|}{ Tab. 6: } & \multicolumn{11}{|c|}{$\begin{array}{l}\text { Normalized and optimized values for Sweden, Denmark, Estonia and Finland } \\
\text { using MULTIMOORA method }\end{array}$} \\
\hline \multirow{2}{*}{ \# } & \multicolumn{3}{|c|}{ Sweden } & \multicolumn{3}{|c|}{ Denmark } & \multicolumn{3}{|c|}{ Estonia } & \multicolumn{3}{|c|}{ Finland } \\
\hline & 2013 & 2014 & 2015 & 2013 & 2014 & 2015 & 2013 & 2014 & 2015 & 2013 & 2014 & 2015 \\
\hline 1. & 0.68 & 0.69 & 0.77 & 0.57 & 0.54 & 0.47 & 0.09 & 0.09 & 0.08 & 0.36 & 0.37 & 0.30 \\
\hline 2. & 0.26 & 0.49 & 0.49 & 0.73 & 0.44 & 0.73 & 0.26 & 0.60 & 0.14 & 0.11 & 0.15 & 0.14 \\
\hline 3. & 0.28 & 0.25 & 0.25 & 0.32 & 0.29 & 0.29 & 0.44 & 0.44 & 0.44 & 0.28 & 0.27 & 0.28 \\
\hline 4. & 0.31 & 0.29 & 0.29 & 0.54 & 0.53 & 0.52 & 0.34 & 0.36 & 0.36 & 0.38 & 0.38 & 0.38 \\
\hline 5. & 0.27 & 0.25 & 0.25 & 0.44 & 0.40 & 0.41 & 0.40 & 0.41 & 0.39 & 0.33 & 0.32 & 0.32 \\
\hline 6. & 0.39 & 0.40 & 0.35 & 0.52 & 0.47 & 0.46 & 0.14 & 0.15 & 0.19 & 0.62 & 0.64 & 0.67 \\
\hline 7. & 0.42 & 0.42 & 0.42 & 0.40 & 0.39 & 0.39 & 0.34 & 0.35 & 0.35 & 0.40 & 0.41 & 0.40 \\
\hline 8. & 0.50 & 0.25 & 0.26 & 0.40 & 0.85 & 0.79 & 0.27 & 0.14 & 0.17 & 0.60 & 0.34 & 0.39 \\
\hline 9. & 0.46 & 0.45 & 0.45 & 0.48 & 0.45 & 0.45 & 0.17 & 0.11 & 0.15 & 0.43 & 0.49 & 0.54 \\
\hline
\end{tabular}

Source: own

Lithuania, Latvia and Poland. To compare to 2013 TOPSIS result, Poland has decreased its rank, while Denmark improved its result.

In Fig. 5 are represented results of Green Economy Dimension evaluation in the context of Circular economy of Baltic Sea Region in 2015.

According to MULTIMOORA results the highest rank received Denmark, Sweden, and Germany, while the lowest rank received Latvia, Poland and Lithuania in the 2015 year. To compare to 2013 results, Latvia improved their results, while Sweden, Poland and Lithuania rank were decreased. According to TOPSIS method, the highest rank received Denmark,
Sweden, Finland and Germany, while the lowest rank received Poland, Latvia and Lithuania in 2015. To compare to 2013 TOPSIS result, Poland and Estonia have decreased their rank, while Denmark improved its result.

Circular economy aligns with sustainability approach and ensures sustainable development by replacing unsustainable linear flow model with the cyclical flow of materials and energy. The economic objective of circular economy is to reduce the economic cost of resources and waste to innovate new environmentally-friendly products and business models (Korhonen, Honkasalo, \& Seppälä, 2018). However, in the current economic

\begin{tabular}{|c|c|c|c|c|c|c|c|c|c|c|c|c|}
\hline & & iali & anc & tim & $\begin{array}{l}\text { va } \\
\text { od }\end{array}$ & $\theta$ & $m$ & La & Li & & $\mathbf{P}$ & \\
\hline \multirow{2}{*}{ \# } & \multicolumn{3}{|c|}{ Germany } & \multicolumn{3}{|c|}{ Latvia } & \multicolumn{3}{|c|}{ Lithuania } & \multicolumn{3}{|c|}{ Poland } \\
\hline & 2013 & 2014 & 2015 & 2013 & 2014 & 2015 & 2013 & 2014 & 2015 & 2013 & 2014 & 2015 \\
\hline 1. & 0.26 & 0.27 & 0.29 & 0.05 & 0.05 & 0.05 & 0.07 & 0.06 & 0.07 & 0.07 & 0.06 & 0.06 \\
\hline 2. & 0.42 & 0.40 & 0.42 & 0.11 & 0.15 & 0.11 & 0.00 & 0.01 & 0.01 & 0.37 & 0.03 & 0.02 \\
\hline 3. & 0.28 & 0.27 & 0.26 & 0.42 & 0.45 & 0.44 & 0.35 & 0.36 & 0.36 & 0.42 & 0.43 & 0.43 \\
\hline 4. & 0.32 & 0.27 & 0.25 & 0.32 & 0.35 & 0.35 & 0.22 & 0.22 & 0.24 & 0.32 & 0.34 & 0.35 \\
\hline 5. & 0.26 & 0.25 & 0.24 & 0.42 & 0.45 & 0.45 & 0.30 & 0.30 & 0.30 & 0.37 & 0.39 & 0.40 \\
\hline 6. & 0.40 & 0.42 & 0.41 & 0.05 & 0.05 & 0.06 & 0.04 & 0.04 & 0.06 & 0.05 & 0.06 & 0.07 \\
\hline 7. & 0.38 & 0.38 & 0.38 & 0.31 & 0.30 & 0.30 & 0.28 & 0.28 & 0.28 & 0.27 & 0.27 & 0.27 \\
\hline 8. & 0.36 & 0.25 & 0.33 & 0.08 & 0.07 & 0.09 & 0.11 & 0.08 & 0.09 & 0.05 & 0.08 & 0.09 \\
\hline 9. & 0.43 & 0.49 & 0.40 & 0.26 & 0.25 & 0.27 & 0.29 & 0.14 & 0.17 & 0.14 & 0.15 & 0.16 \\
\hline
\end{tabular}




\section{Fig. 3: Green Economy Dimension evaluation of Baltic Sea Region in 2013}

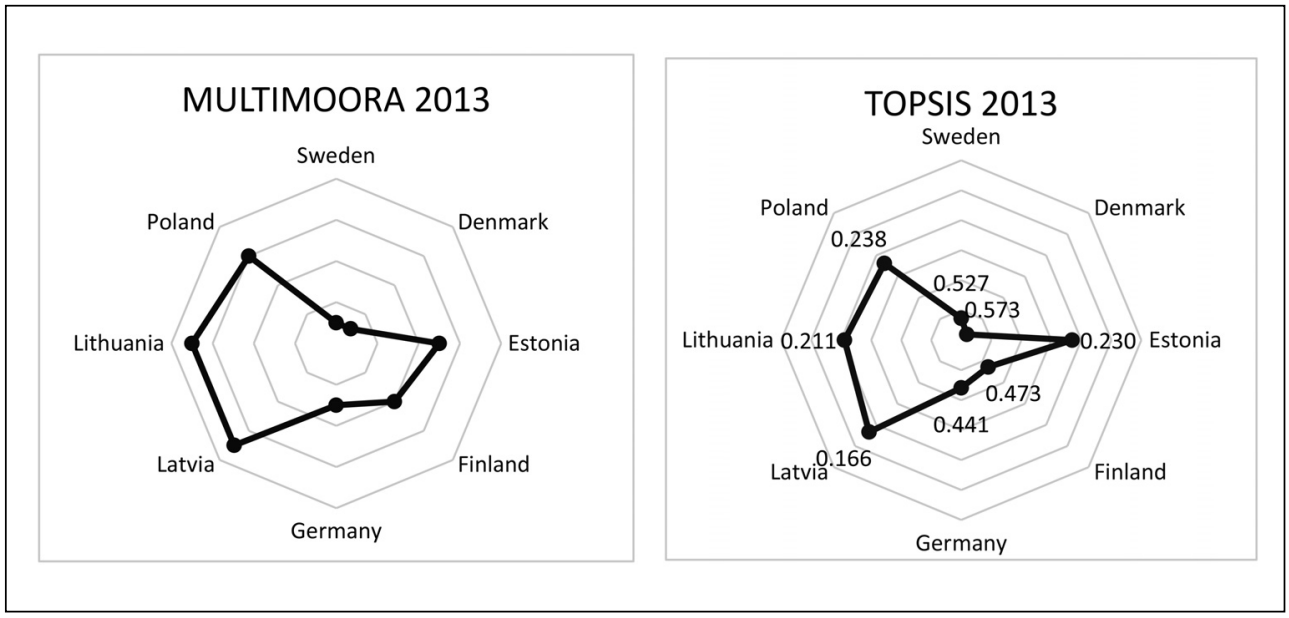

Source: own

model environmentally-friendly technologies are not always economically beneficial (Ottelin, Heinonen, \& Junnila, 2018). For that reason, strong environmental economic policies should be launched to increase the implementation and investments in environmentally-friendly technologies. Furthermore, environmental regulations together with governmental regulations could be strategically used to increase the interest in "green" investment (Pekovic, Grolleau, \& Mzoughi, 2018). Banks, as financial institutions, could influence the popularity of "green" investments by launching banking regulation policies aimed to support "green" investment (Raberto, Ozel, Ponta, Teglio, \& Cincotti, 2019). The banks may

\section{Fig. 4: Green Economy Dimension evaluation of Baltic Sea Region in 2014}
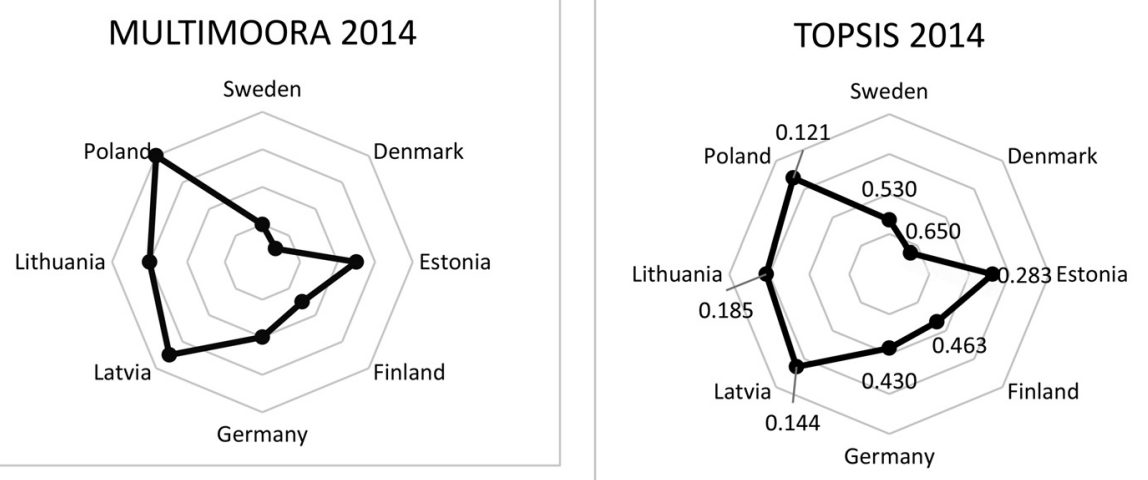


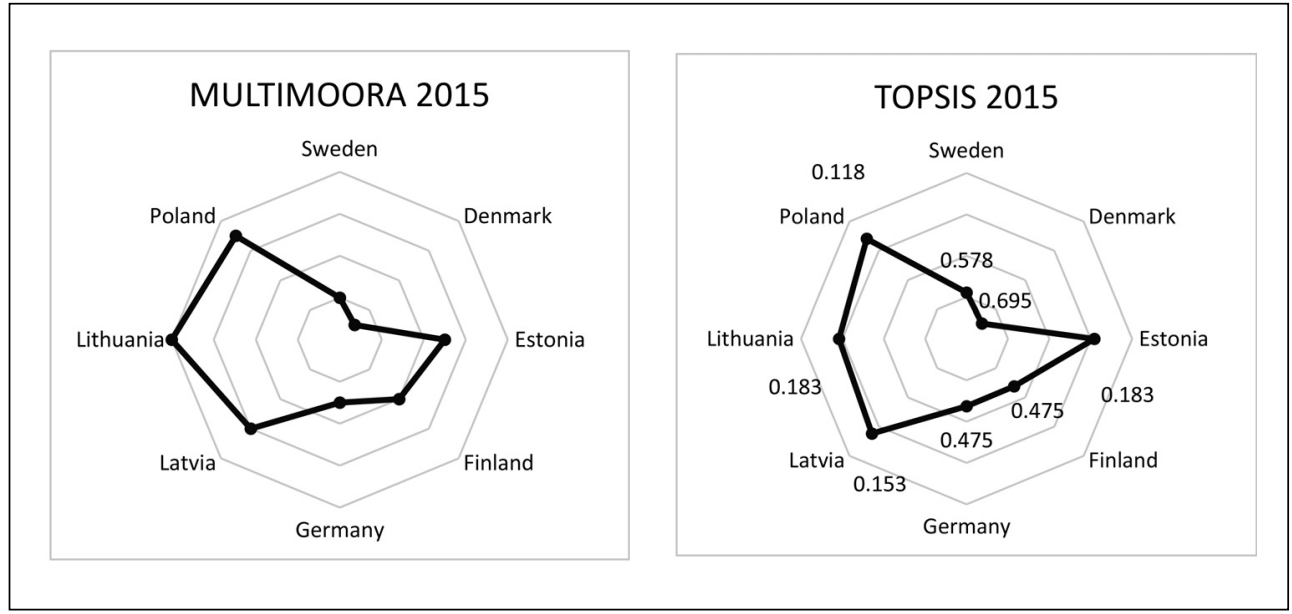

Source: own

reduce the green investment gap by lowering lending requirements and directing credit towards green sector. Central banks could play a significant role in shifting towards circular economy by financing green transformation, allocating resources toward circular economy and responding to sustainability challenges. Central banks could impact investment decisions including disclosure requirements and Green Macroprudential Regulation and directed green credit policy instruments (United Nations, 2017).

Moreover, green technologies and innovations could be stimulated by environmental taxes (Shmelev \& Speck, 2018). The benefit from the environmental taxes could occur in the case of reinvesting some of the revenues of environmental taxes in ecoinnovation and green technologies what would lead to increase of employment, popularity of green products and increased efficiency of technology. Environmental Tax reforms were implemented in several EU countries including Sweden, Germany, Denmark and Finland, which shifted the tax burden from labour taxation towards taxation of carbon and energy.

\section{Conclusions}

The circular economy is based on the synergy of Economic, Environmental and Social Dimensions on -micro, -meso and -macro levels. According to the concept of the circular economy, goods at the end of their lives are turning material to produce new products. This process minimises or insures zero waste of resources. Green economy dimension can be analysed using the synergy of Economic, Environmental and Social aspects and three major groups can be identified: Green investment, Green fiscal policy and Technological development.

The Baltic Sea Region was selected to evaluate the Green economy dimension in the context of circular economy in the period of 2013-2015. Two MCDA (MULTIMOORA and TOPSIS) methods were performed. These methods are suitable for green economy assessment because the framework can evaluate different units of measurement. Additionally, the use of two different MCDA methods is in the light of getting results that are more robust by applying triangulation regarding used method.

According to the MULTIMOORA MCDA method result, the green economy dimension in the context of circular economy in the period of 2013-2015 was ranked by the highest rank following countries: Denmark, Sweden, and Germany, while the lowest rank received following countries: Latvia, Poland and Lithuania. During the years 2013-2015 Latvia improved mostly the results of green economy 
dimension, while Sweden, Poland and Lithuania have decreased in the rank to compare to 2013.

According to TOPSIS method, the green economy dimension in the context of circular economy in the period of 2013-2015 was ranked by the highest rank following countries: Denmark, Sweden, Finland and Germany while the lowest rank received Poland, Latvia and Lithuania by the end of 2015. According to the TOPSIS results Poland and Estonia have decreased their rank, while Denmark improved its result by the end of 2015 to compare to 2013.

The results of two methods used to assess green economy dimension in the context of the circular economy are very similar and the ranking of Baltic Sea Region countries in the period of 2013-2015 corresponds. By this, the model can be used to assess green economy dimension in the context of circular economy for further scientific research, government strategic decision making, business processes and statistics.

This study contributes to the stock of knowledge in at least in two ways. Firstly, it is a value-added to the present debate on sustainability and on the ways to get there. When it comes at sustainability, scholars have discussed it along with circular, green and bioeconomy (D'Amato, Droste, Winkler, \& Toppinen, 2019; D’Amato, Korhonen, \& Toppinen, 2019; Gregorio et al., 2018). The use of the triangulation technique by employing two different methods to achieve our aim, give extra credits to this paper.

Even though the aim of the paper was achieved, there are some limitations in the current research. Firstly, circular and green economy are relatively new concepts in the field of study (Kirchherr et al., 2017). It led to the fact that green economy might be measured differently from how was proposed in this paper. Secondly, we used secondary data covering the years from 2013 to 2015. More extended time series may provide a better picture of getting towards sustainability through green economy perspective.

\section{References}

Barbier, E. (2012). Sustainability. The green economy post Rio+20. Science, 338(6109), 887-888. https://doi.org/10.1126/ science. 1227360

Brauers, W. K. M., \& Zavadskas, E. K. (2010). Project management by MULTIMOORA as an instrument for transition economies. Technological and Economic Development of Economy, 16(1), 5-24. https://doi.org/10.3846/ tede.2010.01

Byun, H. S., \& Lee, K. H. (2005). A decision support system for the selection of a rapid prototyping process using the modified TOPSIS method. The International Journal of Advanced Manufacturing Technology, 26(11-12), 1338-1347. https://doi.org/10.1007/s00170-004-2099-2

Cheng, Z. (2016). The spatial correlation and interaction between manufacturing agglomeration and environmental pollution. Ecological indicators, 61(2), 1024-1032. https://doi.org/10.1016/j.ecolind.2015.10.060

D'Amato, D., Droste, N., Allen, B., Kettunen, M., Lähtinen, K., Korhonen, J., ... Toppinen, A. (2017). Green, circular, bio-economy: A comparative analysis of sustainability avenues. Journal of Cleaner Production, 168, 716-734. https://doi.org/10.1016/J.JCLEPRO.2017.09.053

D'Amato, D., Droste, N., Winkler, K. J., \& Toppinen, A. (2019). Thinking green, circular or bio: Eliciting researchers' perspectives on a sustainable economy with $Q$ method. Journal of Cleaner Production, 230, 460-476. https://doi.org/10.1016/J.JCLEPRO.2019.05.099

D'Amato, D., Korhonen, J., \& Toppinen, A. (2019). Circular, Green, and Bio-Economy: How Do Companies in Land-Use Intensive Sectors Align with Sustainability Concepts? Ecological Economics, 158, 116-133. https://doi.org/10.1016/j.ecolecon.2018.12.026

European Commission. (2014). Towards a circular economy: A zero waste programme for Europe, Communication from the commission to the European Parliament, the Council, The European Economic and Social Committee and the Committee of the Regions. Brussel. Retrieved from https://ec.europa.eu/ environment/circular-economy/pdf/circulareconomy-communication.pdf

EUROSTAT. (n.d.). Primary production all products - annual data. Retrieved June 22, 2019, from http://appsso.eurostat.ec.europa. eu/nui/show.do?dataset=nrg_109a\&lang=en

Garud, R., \& Gehman, J. (2012). Metatheoretical perspectives on sustainability journeys: Evolutionary, relational and durational. Research Policy, 41(6), 980-995. https://doi. org/10.1016/J.RESPOL.2011.07.009

Gasparatos, A., Doll, C. N. H., Esteban, M., Ahmed, A., \& Olang, T. A. (2017). Renewable energy and biodiversity: Implications for 
transitioning to a Green Economy. Renewable and Sustainable Energy Reviews, 70, 161-184. https://doi.org/10.1016/J.RSER.2016.08.030

Geissdoerfer, M., Savaget, P., Bocken, N. M. P., \& Hultink, E. J. (2017). The Circular Economy - A new sustainability paradigm? Journal of Cleaner Production, 143, 757-768. https://doi. org/10.1016/J.JCLEPRO.2016.12.048

Gregorio, V. F., Pié, L., \& Terceño, A. (2018). A Systematic Literature Review of Bio, Green and Circular Economy Trends in Publications in the Field of Economics and Business Management. Sustainability, 10(11), 4232. https://doi.org/10.3390/su10114232

Gupta, J., \& Vegelin, C. (2016). Sustainable development goals and inclusive development. International Environmental Agreements: Politics, Law and Economics, 16(3), 433-448. https://doi.org/10.1007/s10784-016-9323-z

Heshmati, A. (2016). AReview of the Circular Economy and its Implementation. International Journal of Green Economics, 11(3/4), 251. https://doi.org/10.1504/IJGE.2017.089856

Howes, M., Wortley, L., Potts, R., Dedekorkut-Howes, A., Serrao-Neumann, S., Davidson, J., ... Nunn, P. (2017). Environmental sustainability: a case of policy implementation failure? Sustainability, 9(2), 165. https://epubs. scu.edu.au/esm_pubs/3179/

Hwang, C.-L., \& Yoon, K. (1981). Multiple Attribute Decision Making. Methods and Applications, A State-of-the-Art Survey (Vol. 186). Berlin, Heidelberg: Springer. https://doi.org/10.1007/978-3-642-48318-9

Ilić, M., \& Nikolić, M. (2016). Drivers for development of circular economy - A case study of Serbia. Habitat International, 56, 191-200. https://doi.org/10.1016/j.habitatint.2016.06.003

Kalmykova, Y., Rosado, L., \&Patrício, J. (2016). Resource consumption drivers and pathways to reduction: economy, policy and lifestyle impact on material flows at the national and urban scale. Journal of Cleaner Production, 132, 70-80. https://doi.org/10.1016/J.JCLEPRO.2015.02.027

Kalmykova, Y., Sadagopan, M., \& Rosado, L. (2018). Circular economy - From review of theories and practices to development of implementation tools. Resources, Conservation and Recycling, 135, 190-201. https://doi. org/10.1016/j.resconrec.2017.10.034

Kirchherr, J., Piscicelli, L., Bour, R., KostenseSmit, E., Muller, J., Huibrechtse-Truijens, A., \& Hekkert, M. (2018). Barriers to the Circular Economy: Evidence From the European Union
(EU). Ecological Economics, 150, 264-272. https://doi.org/10.1016/j.ecolecon.2018.04.028

Kirchherr, J., Reike, D., \& Hekkert, M. (2017). Conceptualising the circular economy: An analysis of 114 definitions. Resources, Conservation and Recycling, 127, 221-232. https://doi.org/10.1016/j. resconrec.2017.09.005

Korhonen, J., Honkasalo, A., \& Seppälä, J. (2018). Circular Economy: The Concept and its Limitations. Ecological Economics, 143, 37-46. https://doi.org/10.1016/j.ecolecon.2017.06.041

Loiseau, E., Saikku, L., Antikainen, R., Droste, N., Hansjürgens, B., Pitkänen, K., ... Thomsen, M. (2016). Green economy and related concepts: An overview. Journal of Cleaner Production, 139, 361-371. https://doi. org/10.1016/J.JCLEPRO.2016.08.024

Lund, P. (2012). The European Union challenge: integration of energy, climate, and economic policy. Wiley Interdisciplinary Reviews: Energy and Environment, 1(1), 60-68. https://doi.org/10.1002/wene.37

Markard, J., Raven, R., \& Truffer, B. (2012). Sustainability transitions: An emerging field of research and its prospects. Research Policy, 41(6), 955-967. https://doi.org/10.1016/J. RESPOL.2012.02.013

Millar, N., McLaughlin, E., \& Börger, T. (2019). The Circular Economy: Swings and Roundabouts? Ecological Economics, 158, 11-19. https://doi.org/10.1016/j. ecolecon.2018.12.012

Murray, A., Skene, K., \& Haynes, K. (2017). The Circular Economy: An Interdisciplinary Exploration of the Concept and Application in a Global Context. Journal of Business Ethics, 140(3), 369-380. https://doi.org/10.1007/ s10551-015-2693-2

OECD. (n.d.). Green Growth Indicators. Retrieved June 23, 2019, from https://stats. oecd.org/Index.aspx?DataSetCode=GREEN_ GROWTH\#

Ottelin, J., Heinonen, J., \& Junnila, S. (2018). Carbon and material footprints of a welfare state: Why and how governments should enhance green investments. Environmental Science \& Policy, 86, 1-10. https://doi.org/10.1016/J. ENVSCI.2018.04.011

Pavić, Z., \& Novoselac, V. (2013). Notes on TOPSIS Method. International Journal of Research in Engineering and Science, 1(2), 5-12.

Pekovic, S., Grolleau, G., \& Mzoughi, N. (2018). Environmental investments: Too 
much of a good thing? International Journal of Production Economics, 197, 297-302. https://doi.org/10.1016/J.IJPE.2018.01.012

Podviezko, A. (2012). Augmenting Multicriteria Decision Aid Methods by Graphical and Analytical Reporting Tools. In Niedrite L., Strazdina R., \& Wangler B. (Eds.), Workshops on Business Informatics Research. BIR 2011. Lecture Notes in Business Information Processing (pp. 236-251). Berlin, Heidelberg: Springer. https://doi.org/10.1007/978-3-64229231-6_19

Puppim de Oliveira, J. A., Doll, C. N. H., Balaban, O., Jiang, P., Dreyfus, M., Suwa, A., ... Dirgahayani, P. (2013). Green economy and governance in cities: assessing good governance in key urban economic processes. Journal of Cleaner Production, 58, 138-152. https://doi. org/10.1016/J.JCLEPRO.2013.07.043

Raberto, M., Ozel, B., Ponta, L., Teglio, A., \& Cincotti, S. (2019). From financial instability to green finance: the role of banking and credit market regulation in the Eurace model. Journal of Evolutionary Economics, 29(1), 429-465. https://doi.org/10.1007/s00191-018-0568-2

Ringel, M., Schlomann, B., Krail, M., \& Rohde, C. (2016). Towards a green economy in Germany? The role of energy efficiency policies. Applied Energy, 179, 1293-1303. https://doi. org/10.1016/J.APENERGY.2016.03.063

Sarkar, A. (2013). A TOPSIS method to evaluate the technologies. International Journal of Quality \& Reliability Management, 31(1), 2-13. https://doi.org/10.1108/IJQRM-03-2013-0042

Scheel, C. (2016). Beyond sustainability. Transforming industrial zero-valued residues into increasing economic returns. Journal of Cleaner Production, 131, 376-386. https://doi. org/10.1016/J.JCLEPRO.2016.05.018
Shmelev, S. E., \& Speck, S. U. (2018). Green fiscal reform in Sweden: Econometric assessment of the carbon and energy taxation scheme. Renewable and Sustainable Energy Reviews, 90, 969-981. https://doi. org/10.1016/J.RSER.2018.03.032

Stahel, W. R. (2016). The circular economy. Nature, 531(7595), 435-438. https://doi. org/10.1038/531435a

Taranic, I., Behrens, A., \& Topi, C. (2016). Understanding the Circular Economy in Europe, from Resource Efficiency to Sharing Platforms: The CEPS Framework. CEPS Special Reports, 143. https://doi.org/10.13140/ RG.2.2.14272.94728

United Nations. (2016). Net official development assistance given or received as a percentage of gross national income. Retrieved from https://data.oecd.org/oda/netoda.htm

United Nations. (2017). On the Role of Central Banks in Enhancing Green Finance (01 No. 17).

UNSD. (n.d.). Environment Statistics Database. Retrieved June 23, 2019, from http://data.un.org/Explorer.aspx?d=CLINO

Vanhamaki, S., Medkova, K., Malamakis, A., Kontogianni, S., Marisova, E., Huisman Dellago, D., \& Moussiopoulos, N. (2019). Biobased circular economy in European national and regional strategies. International Journal of Sustainable Development and Planning, 14(1), 31-43. https://doi.org/10.2495/SDPV14-N1-31-43

Vasiljevic-Shikaleska, A., Gjozinska, B., \& Stojanovikj, M. (2017). The circular economy - a pathway to sustainable future. Journal of Sustainable Development, 7(17), 13-30. Retrieved from http://www.fbe.edu.mk/JSDv17.pdf 